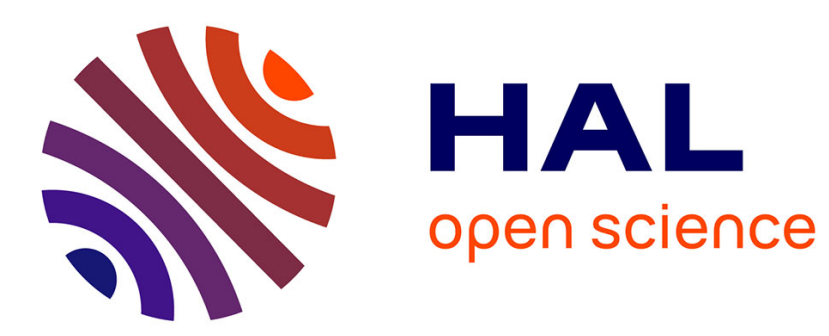

\title{
Afterword: conditions for a new social dialogue in Europe
}

Bernard Gazier

\section{To cite this version:}

Bernard Gazier. Afterword: conditions for a new social dialogue in Europe. Renata Semenza; François Pichault. The Challenges of Self-Employment in Europe, Edward Elgar Publishing, pp.222 - 228, 2019, 9781788118446 . 10.4337/9781788118453 . hal-03213182

\section{HAL Id: hal-03213182 https://hal.science/hal-03213182}

Submitted on 30 Apr 2021

HAL is a multi-disciplinary open access archive for the deposit and dissemination of scientific research documents, whether they are published or not. The documents may come from teaching and research institutions in France or abroad, or from public or private research centers.
L'archive ouverte pluridisciplinaire HAL, est destinée au dépôt et à la diffusion de documents scientifiques de niveau recherche, publiés ou non, émanant des établissements d'enseignement et de recherche français ou étrangers, des laboratoires publics ou privés. 


\section{<FRESH PAGE>}

\section{<ct>Afterword: conditions for a new social dialogue in}

\section{Europe}

\section{$<$ au>Bernard Gazier}

Entitling independent workers to social rights and social protection, and ensuring that they earn decent incomes and have some control over their personal and professional lives, has become a major challenge of our time. Self-employed professionals represent here a key stake, because they are skilled, they are mere workers and do not possess the traditional capital and assets of entrepreneurs, and they have been the most dynamic part of the workforce since the beginning of the century. They represent, in a context of enduring unemployment and precarity in the European Union, one central way of developing employment and diversifying careers.

However, they do not fit into the classical processes of social dialogue, which were devised and implemented for salaried workers many years ago. The classical rationale for organizing salaried workers is that they suffer from a pervasive and structural inferiority versus employers, and then should benefit from a counteracting set of institutions, through labour law and collective negotiation. While employers, organized too, may find advantages in these collective arrangements (through a more stable, productive and predictable workforce), independent workers have been largely left out.

This situation is now increasingly regarded as unsatisfactory, not only because the number of these workers is increasing, but also because the classical salaried workers group now is at best stable and more often shrinking and undergoing profound transformations. New risks are appearing in the labour market, most of them related to the increased discontinuity of work trajectories. Stability for independent professional workers could be achieved through management of the increasingly discontinuous careers of many different types of workers: salaried workers looking for a more independent way of working and living; unemployed persons looking for alternatives, either temporary or permanent; purely independent, benevolent workers in non-profit projects; classical salaried workers or retired workers looking for an income complement, and so on. The debate narrows down to supporting diversified and even 'oblique careers', of which one central part is independent work. 
The challenges and possible action fields for the European Union will be discussed in two steps. First, using the traditional definition of social dialogue, trends and challenges affecting this norm in the European Union will be examined briefly. The specific needs of these new workers will also be considered, connected to the rich potential resources they could provide. However, exploitation of these resources can only be achieved if one goes beyond the traditional social dialogue, and an enlarged version is considered. Second, three main strategies for bringing more rights and protection to these workers have been distinguished in the previous chapters. These will be examined in the context of such a renewed social dialogue and shown that they should act as complements rather than competing or substitute strategies. The possible roles of member states and the European Union in favouring this new social dialogue will be sketched, mainly through support for a positive interplay between the three strategies.

\section{$<\mathbf{a}>1$. FROM A CLASSICAL VERSION TO AN ENLARGED VERSION OF SOCIAL DIALOGUE}

Social dialogue has four components and begins with (i) information sharing and is mainly (ii) centred on negotiating wages, working time and working conditions. It also may include (iii) participation in the management of social security organizations, and ends in (iv) participation in the management of firms. Components (i) and (ii) are universal and without them there is no social dialogue. These cases, dialogue containing only the first two components, are typical of Anglo-Saxon countries. In other countries and especially in the European Union, one finds cases with three or four components. The differences across countries arise from the importance and intensity of each component, and from the way they may interact. In a nutshell, Nordic and Germanic countries have developed social dialogue with all four components, in an intensive way. Information sharing leads then to concertation, and negotiating occurs with strong, centralized and representative partners. Participation in the management of social security organizations and firms, through 'co-determination', is unevenly but usually well developed. In other countries, mainly in Southern Europe, a less intense and more sketchy set of institutions and practices can be observed: information remains asymmetric and does not lead to concertation, and negotiations are more decentralized and are led by less structured and less coherent partners. Participation in management presents a very uneven picture. In some countries, social partners really participate and in others they have only a minority position, sometimes only symbolic, decisions being taken without them (Gazier and Bruggeman 2016). 
This complex and uneven architecture has been and is under pressure since the beginning of the century. Among the main trends and challenges, one can mention the strong tendency, encouraged by the European Union, towards more decentralized bargaining, and a strong tendency, here also reinforced by the European Union, towards less binding labour law arrangements and towards deregulation. While in many countries collective agreements have been extended to firms and workers of a whole branch or sector, sometimes automatically, these 'covering' practices have been lessened or made optional. Another source of weakness of European social dialogue lies in the social partners themselves, especially in the shrinking demography of unions: their membership is declining and militants are often ageing men in industrial sectors, in a world where services, women and young workers are becoming more important. However, it should be observed that this tendency mainly affects unions in the south of Europe.

Against this rather gloomy picture, one can easily insist on the needs and potential of independent professionals. While traditional salaried workers may feel that they are well protected (as long as they do not suffer from unemployment) and then become less militant and even passive in one way or another, these workers may feel that they have to build a new world to represent and protect them. They are, to some extent, in the same position as the 'Sublimes' were in nineteenth-century French social history: highly skilled, independent workers, at the same time individualistic and solidary. During the 1860s and 1870s, these Parisian workers were precisely at the very origin of mutual help institutions and funds, and at the origin of French unions.

Let us be precise in discussing the context of current action for the self-employed professionals of today. While independent and sometimes isolated, they face networks of firms and may build networks of workers, working spaces, mutual help funds and co-working spaces. They can, and many of them effectively do, combine individualistic traits with collective engagement.

However, it is quite clear that the traditional social dialogue can neither integrate nor support their action. What is needed is a renewed form of social dialogue - it already exists, but in a patchy way. Let us start from the three basic functions performed by social dialogue: ensuring social integration, balancing the diverging interests of social partners and distributing income and resources, and coordinating projects. While the second function has been and remains the main one, the other two are of prominent importance and now become central. For example, if one considers the fate of precarious workers and subcontracting firms in a context of restructuring, the representation of the interests of such actors is mainly absent 
from classical negotiations over the restructuring process. A renewed version of social dialogue should integrate them, probably mainly on a territorial basis. The process then is an enlarged version of collective negotiation, with new actors and new objects. The new actors' list comprises territorial actors such as municipalities, regions, professional networks and associations. The new objects of negotiation add to the traditional agenda project initiatives such as creating additional and specific social protection devices, intensive training and retraining, social follow-up, and so on.

In this enlarged landscape, the emerging collective actors of independent professionals should play an important role through diversified practices which have been presented in Chapter 6, such as offering services, lobbying, and taking part in negotiations over income guarantees, holidays, training rights, and so on. One can understand the emerging enlarged social dialogue as an integration of the four components presented above, either on a territorial basis or on a branch/sector basis. The tendency towards more decentralized negotiations noted above has then to be reconsidered, leading not only to plant by plant negotiations over wages and working conditions, but also to territorial and branch-wide negotiations - a recomposed, intermediate level of dialogue and coordination.

\section{$<\mathbf{a}>2$. THE EU IN FRONT OF THREE COMPLEMENTARY STRATEGIES}

What could the role of the European Union be in such a complex and emerging process? What kind of social dialogue could be adopted and what would it contain? Of course, current practices in EU member states are highly diverse and there is no 'one-size-fits-all' perspective here.

One may start from one of the main results of the study: the identification of three main national strategies aiming at better protecting independent workers, all of them being present in each member state to some extent, and all of them with advantages and limits. We will see that these strategies may justify European Union interventions, but involve very different modalities.

The first strategy consists in exploiting the stabilization potential of a salaried relationship for at least some independent workers. It entails two very different versions. The first one is the 'reclassification' strategy, used in some sectors for protecting 'economically dependent' independent workers, transforming them into salaried workers. As has been seen in 2017 for Uber drivers in California, this version concerns the so-called 'bogus' independents, because in fact their employment situation is very close to that of salaried workers. Two limits are observed here. First, this strategy cannot concern 'real' independent workers, but only a quite 
small fraction of them (say, less than 6 per cent). Second, some of these workers may not be willing to be considered as salaried workers, and may prefer to be considered as independent, and protected in another manner. However, a second version exists, more successful at least in some countries. It is opening access, to some groups of independent workers, to the social protection advantages of salaried workers. This technique of partial assimilation may concern independent workers in the entertainment and art sectors, but also workers acting as managers and entrepreneurs inside firms. It has also been developed for skilled workers delivering intellectual services, for example in the case of 'portage salarial'. The survey presented in Chapter 3 has shown that such arrangements, if not easily readable for other workers, do bring objective and subjective protection to the workers concerned. The arrangements' limits are easy to acknowledge: these workers are effectively protected if they succeed in getting enough hours of work, either beyond an official threshold (as is the case of the French 'intermittents du spectacle' regime) or simply for earning sufficient income from fragmented and unstable work opportunities. So there is a double risk of segmentation: first, for the workers in such sectors unable to get enough hours, who may be left out or left with insufficient income and protection, and second, for the independent workers in other sectors, operating under less favourable schemes. Such strategies can be extended only if they are combined with other, more general strategies, entitling non-covered independent workers to substantial inclusion and guarantees.

The second strategy is the reverse of the first one. It is a general and 'universal' strategy: developing a basis for social rights for every member of the workforce. This can be achieved in two ways. First, by setting a universal social protection scheme, either ambitious (as is the case in Nordic countries, cf. the case of Sweden presented in Chapter 4, Section 9) or more limited (as is the case in transitioning and less advanced countries, such as Slovenia, as we can see in Chapter 4, Section 7). A second way is to develop some enabling transversal rights, such as training rights or unemployment insurance rights, which can be granted to several categories of workers beyond salaried workers. A technique for developing such rights is to implement 'social drawing rights', rights that can be activated under some circumstances or at some period of the life course. Such strategies may be very costly because their intent is to cover a very large population with very different needs and contributory capacities. If governments choose to limit their costs by limiting their extent and intensity, they could become more cosmetic than real or result in a minimal form of safety net. Here again, segmentation is a serious concern. While the most skilled may take 
advantage of transversal rights, less-equipped and less-skilled workers may simply not make use of their rights.

The last strategy is a bottom-up one and relies more directly on social dialogue: organizing independent professionals through organizations. Through networks, mutual funds, services and lobbying at different levels, and unions and quasi-unions, one can improve the living conditions and social protection of diverse groups of independent workers. This strategy and its ramifications have been explained in Chapter 6. Among the main results, it has been shown that it will necessarily remain unevenly implemented but is always relevant because it fosters autonomy and collective self-management. One interesting trait here is the diversity of application fields, from additional social protection to negotiations, aiming at ensuring a minimal price for services delivered through platforms. The stake here for the EU and its member states is developing a rich ecosystem of agile collective actors, able to perceive and elaborate the needs of these workers and to integrate isolated professional workers into groups of peers. The networking of these heterogeneous actors is an obvious way to improve their influence and legitimacy.

These three strategies are present, in a way or another, in all the national cases which have been studied in the I-WIRE project. Each strategy has strengths and drawbacks, and the view emerging from the book is that they should be more deliberately combined in order to reinforce each other and to act as complements rather than competing options. The risk of transversal rights remaining symbolic only can be overcome if two conditions are met: first, these rights should be effectively connected to other securing guarantees. As these guarantees may remain closed to workers not enrolled in the schemes or not fulfilling all the required conditions for being integrated, one needs to develop general protections and transversal rights to be given to any kind of worker in any kind of situation. Second, national and European interventions should fight against the abuses of subcontracting and restore the responsibility of principal firms and platforms. There is here ample room and need for political choices beyond the technical ones.

In order to develop the new social dialogue, policymakers in the European Union should take seriously two challenges which should be transformed into opportunities. The first one is the long-term consequences of the tendency towards decentralizing collective bargaining. As we have seen, the emerging new economy is one of networks and collaborative actors, and in this context the decentralization process is not a simple and univocal one. It should be reinterpreted as not only the priority of connecting the needs and resources of individual actors and firms in local contexts, but also the creation of new fields of solidarity and co- 
decision in branches and territories. The second challenge is the current state of slow growth in Europe as well as in most of the developed world. While things seem to have improved ten years after the global financial crisis in 2008, mid-term and long-term prospects remain modest. If so, and whatever the causes may be (ecological concerns as well as ill-explained productivity slowdown), economies and societies have to adapt. Accordingly, in a context where the creation of additional hours of paid work seems hampered, the idea of a worksharing process through the whole life course is gaining momentum. It should be a flexible and even reversible one, for example through parental or training leaves.

In both domains, the needs and experience accumulated by self-employed professionals are central. The new social dialogue is a necessity not only for them but for all other workers and for society as a whole.

\section{$<\mathbf{a}>$ REFERENCES}

Gazier, B. and Bruggeman F. (2016), 'Dialogue social et dialogue social territorial au début du XXIe siècle. Un essai de théorisation', Négociations, 2, 55-72. 